\title{
Entre-mundos: a travessia dos refugiados do nazifascismo. Brasil, 1933-1945
}

Resumo:

Este artigo tem como proposta sensibilizar o nosso leitor para o tema das migrações forçadas pela violência nazista que, a partir de 1933, tiveram consequências para além da Europa, incluindo vários países da América Latina. Perseguido, assustado e humilhado pela Alemanha nazista e países colaboracionistas, o judeu não tinha para onde ir, pois nem todas as nações expressavam o desejo de adotá-lo como cidadão, como ser humano portador de um nome e raízes próprios. Entre aqueles que optaram pelo Brasil como refúgio, provisório ou permanente, identificamos centenas de artistas, escritores e cientistas que transformaram suas obras em libelos contra a intolerância. Através da produção artística e literária deste grupo, pretendemos avaliar suas percepções diante da Europa destruída pela barbárie nazista, interpretar seus traumas, suas visões de "abismos" no contexto do caos e o significado da vida diante da morte possível.

Palavras-chave:

Arte, Brasil, Imigração, Judeu, Holocausto, Literatura, Nazismo

\section{Abstract:}

This article aims to sensitize our reader to the issue of forced migrations by Nazi violence that, from 1933 onwards, had consequences beyond Europe, including several countries in Latin America. Persecuted, frightened and humiliated by the national socialist state and collaborationist countries, the Jew had nowhere to go, as not all nations expressed the desire to adopt him as a citizen, as a human being bearing his own name and roots. Among those who chose Brazil as a refuge, temporary or permanent, we identified hundreds of artists, writers and scientists who turned their works into libels against intolerance. Through the artistic and literary production of this group, we intend to assess their perceptions of Europe destroyed by Nazi barbarism, interpret their traumas, their visions of "abysses" in the context of chaos and the meaning of life in the face of possible death.

Keywords:

Art, Brazil, Immigration, Jew, Holocaust, Literature, Nazism 


\section{Brasil, um refúgio nos trópicos}

Consideramos que as imigrações forçadas trazem lições universais relevantes para todos os países, pois o Holocausto não afetou apenas as populações diretamente violentadas pelos crimes nazistas. Os discursos de ódio e as ações genocidas praticadas pela Alemanha e países colaboracionistas entre 1933-1945 tiveram consequências para além da Europa, incluindo o Brasil que, entre 1937-1949, adotou uma política antissemita para barrar a entrada de judeus que fugiam da barbárie nazista. Entre aqueles que optaram pelo Brasil como um refúgio nos trópicos, provisório ou permanente, identificamos centenas de artistas, escritores e cientistas cujo legado merece ser reconstituído.

Daí a minha preocupação em diferenciar este grupo (refugiados e/ou exilados europeus, em grande parte judeus do Leste Europeu) dos imigrantes que, desde 1810, vieram por espontânea vontade, ainda que fugindo das revoluções, da fome e da miséria na Europa. Os refugiados judeus que começaram a desembarcar no Brasil a partir de 1933 foram forçados a deixar suas comunidades de origem, movidos pela xenofobia e pelo antissemitismo que colocavam em risco suas vidas. Até então, a consciência da possibilidade de um genocídio iminente (palavra cunhada por Rafael Lemkin em 1944) ainda não havia se consolidado. As primeiras instituições e instrumentos jurídicos de proteção aos refugiados russos, armênios e alemães criados nos anos 20 e 30 - a exemplo do Alto Comissariado para os Refugiados Russos, assumido por Fridtjot Nansen - não davam conta do novo cenário de perseguições empreendidas pelo Terceiro Reich. Somente após a Segunda Guerra Mundial é que ocorreria a institucionalização do instituto de refúgio com a aplicação da Convenção de 1951 Relativa ao Status dos Refugiados. (Jubilut et alli 2018; 2017)

Nas décadas de 30 e 40, a falta de experiência das nações em tratar uma crise humanitária global, caracterizada pela grande quantidade de indivíduos definidos como apátridas, favoreceu a execução do Plano de Solução Final para a Questão Judaica idealizada pela Alemanha nazista. A esta condição acrescentamos a eficácia da propagação dos mitos políticos, a reciclagem dos discursos de ódio, o apoio de legisladores, cientístas e intelectuais, que sustentados por uma rede estatal de propaganda, contribuíram para a demonização do "outro" em nome de uma Alemanha que pretendia ser "ariana pura". Um conjunto de outros tantos elementos favoreceram as ações genocídas dos perpetradores que, certamente, perceberam ser possível realizar impunemente uma das maiores violações massivas de direitos humanos e de crimes contra a humanidade da era moderna.

Em consequência da violência extrema, o Brasil encontrou diante de si um novo personagem: o refugiado judeu, tema analisado no meu livro Cidadão do Mundo. 0 Brasil diante do Holocausto e dos Refugiados do Nazifascismo (Carneiro 2010). Tornado apátrida pelo nacional-socialismo alemão, esse cidadão passou a vagar pelo mundo em busca de um refúgio seguro que lhe garantisse as mínimas condições de sobrevivência. Neste contexto, a ausência de nacionalidade juridicamente reconhecida por um Estado deve ser entendida no âmbito do Estado-Nação e, neste sentido, tem relação direta com o conceito de soberania nacional. Este direito de ditar regras, por exemplo, foi aplicado pela Alemanha nacional-socialista que, ao retirar aos judeus alemães o direito de cidadania, materializava o fenômeno da apatridia. Assim, a partir do 
momento que o sistema estatal alemão criou formas de gerenciamento dos espaços públicos e das comunidades judaicas dispersas por seus territórios, incluindo aqueles ocupados durante a Segunda Guerra, os judeus passaram a viver situações extremas de exclusão. Tratados como uma ameaça à soberania nacional e à cultura germânica legitimada por uma visão racista, os judeus sentiram-se obrigados a trocar a liberdade por segurança. Transformado no principal alvo da violência estatal, o judeu passou a ser visto como um indíviduo "despersonalizado", sem direitos e sem deveres para com a sua pátria-mãe, agora indefinida. Essa sensação de não-pertencimento forçou-os a assumir disfarces e, até mesmo, viver na "invisibilidade", estratégia para fugir das perseguições. Aliás, este é um dos trunfos da ideologia totalitária: transformar os indívíduos em meros objetos, reduzindo-os à categoria de seres sub-humanos, sem identidade.

Perseguido, assustado e humilhado pelo Estado nazista e países colaboracionistas, o judeu não tinha para onde ir, pois nem todas as nações expressavam o desejo de adotá-lo como cidadão, como ser humano portador de um nome e raízes próprios. Sua imagem/identidade encontrava-se desgastada pela propaganda antissemita que, como um vírus, proliferava pelos quatro cantos do mundo alimentando sentimentos de ódio e repulsa. As Américas, infelizmente, não ficaram encólumes ao antissemitismo sustentado pela Estado alemão e endossado por outros países europeus. As palavras párias, proscrito, profugo (desertor), traídor e degenerado, ocuparam espaço nos documentos oficiais e diplomáticos, na imprensa e nos livros didáticos, como códigos simbólicos de comunicação, carregados de subjetividade por seus tons depreciativos. Em qualquer situação, a figura daquele que foi expulso da sua pátria extrapolava a ideia de fuga, pois seu destino não tinha fronteiras definidas. Sua identidade perpassava por "zonas cinzentas", visto que a matriz identitária estava fragilizada, corroída pelos paradígmas totalitários.

Nesse sentido, considero da máxima importância os estudos e as políticas públicas que denunciem a indiferença dos governos e dos indivíduos em relação à difícil condição das pessoas consideradas "indesejáveis" por sua religião, "raça", gênero, religião, ideologia política etc. Empreitadas como estas investem contra as frentes revisionistas e negacionistas que, nestes últimos anos, têm relativizado a memória do Holocausto e a magnitude das políticas genocidas adotadas pelo nazismo e o fascismo. Entendo que este periodo (1933-1945) é um dos mais sombrios da história das sociedades ocidentais - ou, como muito bem definiu Eric Hobsbawm em sua história do "breve" século XX, é uma "Era dos Extremos" (Hobsbawm 1995).

Este tem sido o núcleo propulsor das minhas investigações cujas raízes remontam ao ano de 1984 quando iniciei meu doutorado sobre antissemitismo na Era Vargas (1930-1945), publicado quatro anos depois. Na sequência, organizei uma grande exposição iconográfica - Brasil, Refúgio nos Trópicos - em parceria com o Instituto Goethe de São Paulo, cujo catálogo homônimo saiu em 1996, em edição bilíngue, alemão e português. Pela primeira vez foram divulgados os nomes e pequenas biografias dos artistas, fotógrafos e intelectuais refugiados do nazifascismo radicados no Brasil. Além de suas raízes identitárias, apresentamos imagens que expunham as razões do refúgio/exílio, as rotas de fuga e as suas obras no campo da literatura 
e das artes. Esta investida incentivou-me a criar em 2009, com recursos Fapesp - Fundação de Amparo à Pesquisa do Estado de São Paulo, a Base de Dados Arqshoah-Arquivo Virtual sobre Holocausto e Antissemitismo, dedicada à história e memória dos judeus refugiados do nazifascismo e dos sobreviventes do Holocausto, a maioria oriunda do Leste Europeu. Desde 2009, o Arqshoah reúne testemunhos daqueles que optaram por viver como exilados ou definitivamente no Brasil: www.arqshoah.com

A partir de 2014, privilegiei uma ampla frente de investigação cujos resultados serão publicados em Travessias - Enciclopedia de Artes, Literatura, Ciências, dedicado a reconstituir o legado dos refugiados do nazifascismo e sobreviventes da Shoah radicados no Brasil a partir de 1933. Através de fontes inéditas e da produção dos artistas, intelectuais e cientístas, pretendo (em conjunto com uma equipe de pesquisadores nacionais e internacionais) avaliar as suas percepções diante da Europa ameaçada pela barbárie nazista, interpretar seus traumas, suas visões de "abismos" no contexto do caos e o significado da vida diante da morte possível.

O conjunto de documentos diplomáticos, obras autobiográficas, literárias e iconográficas até então reunidos na Base de Dados Arqshoah, permitem recuperar o diálogo entre o racional e o irracional que nos remete às questões existenciais. As representações sobre o Brasil, por sua vez, nos colocam diante de homens e mulheres divididos que, expulsos de suas pátrias, saíram em busca de novas formas de estar-no mundo, ainda que vivendo entre-mundos. Suas histórias foram, muitas vezes, silenciadas pelos aparatos oficiais do Estado, ignoradas pela historiografia ou então esquecidas nos arquivos familiares. Tais trajetórias, se cruzadas, têm em comum a violência totalitária e as dificuldades impostas pela política antissemita adotada pelos seus países de origem. Os testemunhos gravados pela equipe Arqshoah, nos ajudam a entender as razões das fugas, dos medos e as marcas dos traumas. A originalidade de cada narrativa está na revelação destes múltiplos mundos (exteriores e interiores) que, no seu conjunto, oferecem uma ampla variedade de engajamentos políticos e culturais.

Sob céus estranhos caminharam milhares de homens e mulheres expulsos de suas pátrias, de todas as idades e nacionalidades. A maioria era composta por judeus forçados pelo Estado alemão a abandonar sua pátria-mãe que, desde a ascensão de Hitler na Alemanha em 1933, não lhes deixou opções de sobrevivência alem da fuga, sem destino certo. Anos depois, as populações judías radicadas nos países ocupados pela Alemanha também foram obrigadas a fugir, com ou sem família, tentando escapar das perseguições que, certamente, os levariam para os guetos e/ou campos de extermínio. Tempos sombrios delineados pela violência totalitária, prelúdio de uma catástrofe cujos motivos são, ainda hoje, incompreensíveis.

\section{Raízes existenciais e identitárias}

Perseguidos, assustados e humilhados pelo Estado nazista, os judeus - tornados apátridas pelo nacional-socialismo alemão - passaram a vagar pelo mundo em busca de um refúgio que lhes garantisse as mínimas condições de sobrevivência. Em fuga, caminhavam como cidadãos do mundo, desterrados sob céus estranhos - reproduzindo aquí o título de um dos livros de Ilse Lieblich Losa (1913-2006), autora de origem alemã, com ascendência judaica, que encontrou 
refúgio em Portugal (Marques 2018). Seus destinos não tinham endereços nem fronteiras. Caminhavam em direção ao infinito, reabilitando a imagem do judeu errante, apontado como o "perigo em trânsito", mito reabilitado pelo discurso e pela literatura antissemitas que ganharam editores, tradutores e leitores na Europa e nas Américas.

As experiências extremas vivenciadas pelos refugiados, exilados e sobreviventes do Holocausto marcaram suas vidas e suas obras, principalmente no caso dos artistas e intelectuais. A violência nazista - que colocou em prática o plano político de uma Alemanha "limpa de judeus" - levou milhares de judeus a repudiarem sua pátria de origem com a impressão de que suas raízes existenciais haviam sido cortadas. Convertidos em apátridas, os judeus - tanto os alemães como aqueles radicados nos países ocupados pela Alemanha - perderam seus direitos o que, por sua vez, debilitava suas referências de pertencimento, cultural e político. Suas trajetórias nos oferecem elementos para um diagnóstico sobre as consequências das imigrações forçadas que ainda persistem neste século XXI. Entre 1933-1945, mais de 340.000 judeus deixaram a Alemanha e a Áustria. Cerca de 100.000 deles encontraram refúgio em países posteriormente ocupados pela Alemanha, sendo deportados ou assassinados pelos atos genocidas dos nazistas e colaboracionistas.

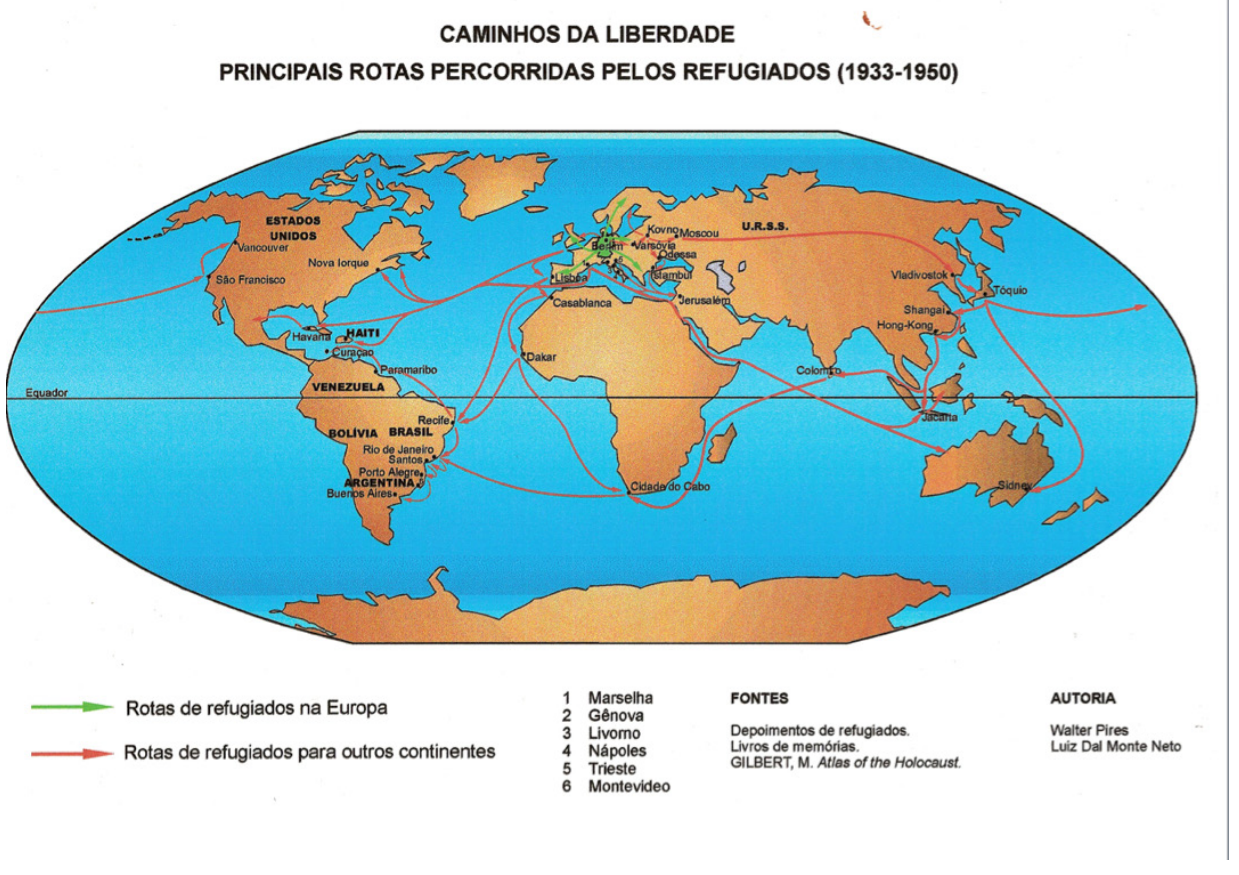

Fonte: Carneiro, Maria Luiza Tucci. Brasil, Refúgio nos Trópicos, op. cit, pp. 104-105. 
Ao perderem a posição de cidadão com todos os direitos garantidos por lei para a categoria de apátrida, os judeus deixavam de "estar-no-mundo" para entrar no "mundo do caos" delineado pela violência sem limites que implicava na desintegração da familia, fragilizada ainda mais com a perda dos seus bens, dos seus empregos e, por consequência, do seu "eu", como muito bem ressaltou Christopher Lasch em sua obra O Mínimo Eu: sobrevivência psíquica em tempos difíceis. Daí a importância de avaliarmos os riscos de desintegração do "eu" nos casos de perda dos marcadores de identidade que, por sí, supõe uma história pessoal. Enfim, pressupõe um constante exercício de sobrevivência:

Em uma época carregada de problemas, a vida cotidiana passa a ser um exercício de sobrevivência. Vive-se um dia de cada vez. Raramente se olha para trás, por medo de sucumbir a uma debilitante nostalgia; e quando se olha para frente, é para ver como se garantir contra os desastres que todos aguardam. Em tais condições, a individualidade transforma-se numa espécie de bem de luxo, fora de lugar em uma era de iminente austeridade. (Lasch 1987: 9)

Assim, as mutações identitárias devem ser avaliadas sob o prisma dos sentidos e das metamorfoses, nem sempre possíveis de serem recuperados pelos documentos institucionais, carimbos nos passaportes e registros fotográficos. Certamente estas fontes ajudam na reconstituição das incríveis rotas de fuga, assim como dos longos tempos de espera, paradas provisórias para aqueles que aguardavam um visto de entrada para qualquer país que os aceitasse como refugiados ou sobreviventes de um genocídio em curso. Pouco se conhece sobre a postura de países que, assim como Portugal e Espanha, se transformaram em pontes para a sobrevivência, além dos exemplos de Xangai e Tanger, por onde passaram muitos artistas e intelectuais que, anos depois, vieram para o Brasil e outros países das Américas. Daí a importância dos testemunhos orais, das autobiografias e das correspondências pessoais (Carneiro 2010: 152, 189n, 190, 289).

No seu conjunto, este corpus documental nos ajuda a reconstituir os momentos de terror, de amor e ódio, sentimentos comuns às vítimas dos genocídios. O momento de optar por uma travessia forçada implicava também na mutação da alma ou seja, num rito de passagem que envolveria a transformação do sujeito, neste caso, o judeu perseguido pela Alemanha nazista e/ou pelos países colaboracionistas. Ao final do trajeto vilumbramos, apesar de todas as dificuldades, um ser com esperanças e instigado a recuperar o seu direito de viver: viver com dignidade, como um cidadão com nome e sobrenome. Fica evidente - nas suas narrativas e outras tantas formas de representação - que o processo de reconquista dos direitos de cidadania exigiu também um árduo processo de reconstrução de identidade.

A história de vida de alguém que passou pelo Holocausto, ou qualquer outra forma de violência genocída, é, como afirmou Lasar Segall, uma "janela aberta para a alma" (Carneiro/ Lafer 2004). Daí a intensa relação da arte, história, fotografia e literatura com a psicanálise, considerando-se que através das narrativas e das representações produzidas pelos artistas e intelectuais conseguiremos verificar como eles lidaram com as mutações de um mundo em 
crise. Retomamos aqui a proposta de Roger Chartier de que, através das práticas discursivas, poderemos "identificar as formas que eles escolheram para reordenar o mundo após o caos, suas noções de distâncias e suas formas diferenciadas de interpretação das novas realidades" (Chartier 2002: 27-28).

Algumas questões instigam as nossas investigações e, certamente, servirão de fio condutor para os estudos sobre as travessias daqueles que conseguiram sobreviver ao Plano de Solução Final da Questão Judaica implementado pela Alemanha nazista. Cabem aqui algumas perguntas que, de certa forma, podem nos ajudar a reconstituir suas visões de mundo e de estar-no-mundo:

- Como o "eu" do poeta, do escritor, do pintor, do fotógrafo ou do escultor conseguiu se manifestar livre dos limites das repressões totalitárias?

- Como o seu poder de criação se projetou fora de qualquer relação de privação ou em processo de libertação?

- Como eles conseguiram se desvencilhar (ou não) da censura, da dor, do medo e dar liberdade ao inconsciente?

- Suas obras podem ser consideradas como manifestos de resistência contra a intolerância e/ ou libelos de protestos?

- Como, enquanto "estrangeiro" em terras brasileiras, esse sujeito observou e registrou suas percepções e impactos diante de uma nova realidade, nem sempre tão exótica?

- Como ele interpretou determinadas motivações e necessidades sociais, como a fome, a pobreza, a crise de moradia, a exclusão social e a violência?

- Como lidou ou dialogou com o poder dominante?

- Quais grupos e sistemas deram suporte para esse sujeito pensar e criar?

Em síntese: após esta "travessia", geográfica e emocional, qual o legado dos refugiados do nazifascimso para a cultura e as ciências brasileiras?

\section{A falta de fundamento}

Para Vilém Fusser (1920-1991) - filósofo checo refugiado no Brasil desde 1940, onde viveu 30 anos, cuja autobiografía encontra-se publicada no livro Bodenlos - estes homens e mulheres vivenciaram situações absurdas, difíceis de serem explicadas, provocando a sensação de que "estavam boiando por falta de fundamento" [Flusser 2007]. Tais sensações implicavam em perdas: perdas das suas referências culturais e da dignidade, em troca da sobrevivência do corpo, um longo e sofrido processo de "perda de fundamento". Nestes momentos, segundo Flusser, o refugiado passa de agente social à posição de um "mero observador".

Enfim, para um diagnóstico destas perdas, devemos levar em consideração as suas culturas nas comunidades de origem e de acolhimento (sendo este temporário para os exilados e permanente para aqueles que optaram pelo Brasil como pátria-mãe). Importante reconstituirmos também os pontos de encontros e situações de desencontros, assim como as redes 
de sociabilidade que, em alguns casos, estenderam-se para as Américas. Suas obras de arte e seus escritos sobre o Brasil (para muitos um país de passagem), nos oferecem alguns "pontos de luz" em meio a uma profunda escuridão, sensação experimentada por muitos. Retomo aqui a descrição feita por Ulrich Becher em seu Brasilianischer Romanzero (Romanceiro Brasileiro) publicado em 1950, que nas linhas e entrelinhas, permite um contraponto com o livro Brasil, um país do futuro (1940), de Stefan Zweig. São olhares distintos que expõem os estranhamentos e que têm em comum a imagem de uma sociedade (imaginada) sem conflitos, como analisou Ruth Bohunovsky em seu artigo sobre Zweig e Becher, ambos exilados no Brasil. (Bohunovsky 2008, 80-99). Assim Becher descreveu os seres humanos que habitavam o morro da Babilônia:

\author{
No morro da Babilônia \\ vivem os pobres em casas de abelha. \\ Na verdade, uma colméia abandonada, \\ na qual se aninhou um bulício não alado. \\ Olhem. Como um asilo de minhocas, apresenta-se \\ o morro babilônico para o observador nas profundezas \\ do colégio militar. Mas ao subir lá, \\ ele precisa pedir muitas desculpas \\ ao seu nariz \\ e admitir: mas aqui vivem seres humanos.
}

(Becher 1962: 25-26)

Sobre o olhar do refugiado como um observador, lembro aqui o comentário bastante simbólico deixado pela artista portuguesa Maria Helena Vieira da Silva (1908-1992), tornada apátrida após seu casamento com o pintor húngaro Árpád Szenes (1897-1985). Desde 1940, após uma longa estadia na França intercalada com uma curta temporada em Lisboa, o casal optou pelo exílio no Rio de Janeiro após receberem passaportes diplomáticos emitidos pela Sociedade das Nações Unidas. Apesar da convivência com importantes artistas e intelectuais locais que frequentavam a residência do casal na antiga Pensão Internacional, em Santa Tereza, Maria Helena transferiu para as sua obras sentimentos de saudade, tristeza e dor. Sentindo-se como uma borboleta em seu casulo mergulhou no próprio silêncio em busca da sua luz interior, assim como testemunhou anos depois:

No Brasil eu estava muito marcada pelos acontecimentos, de maneira que eu vivia um pouco mais com a cabeça na Europa. Por isso eu conheci muito pouco o Brasil. [...] Conheci um bocadinho do povo, pessoas muito simpáticas, boas, inteligentes, muito honestas tambem. Naquela época não podíamos viajar pelo país, a vida era difícil, mas na Europa vivia-se mal. Quer dizer, para nós já era um milagre a gente viver como vivia no Brasil.[...] Sentíamos tudo muito frágil. Vivíamos assim como uma borboleta. [...] (Vieira da Silva 1986, s/p) 
Posicionando-se como uma estranha no mundo tropical brasileiro, Vieira dividia seus pensamentos com os acontecimentos que abalavam a Europa. Movida pelas incertezas, criou seus próprios labirintos expressionistas, escuros, fragmentos de uma "totalidade inconcebível", como assim os descreveu Gisela Rosenthal em seu estudo sobre Vieira, À procura do espaço desconhecido (1998). Distante do seu círculo de amigos e angustiada com as notícias sobre a guerra na Europa, voltou-se para sí mesma, transformando seu ateliê instalado na Pensão Internacional em um casulo. Expressivo destes seus momentos são as telas de Árpad Szenes: Maria Helena VI (1942), retratada dentro de uma casca de noz, cenário e personagem retomados na obra Vieira da Silva em seu ateliê (1946).

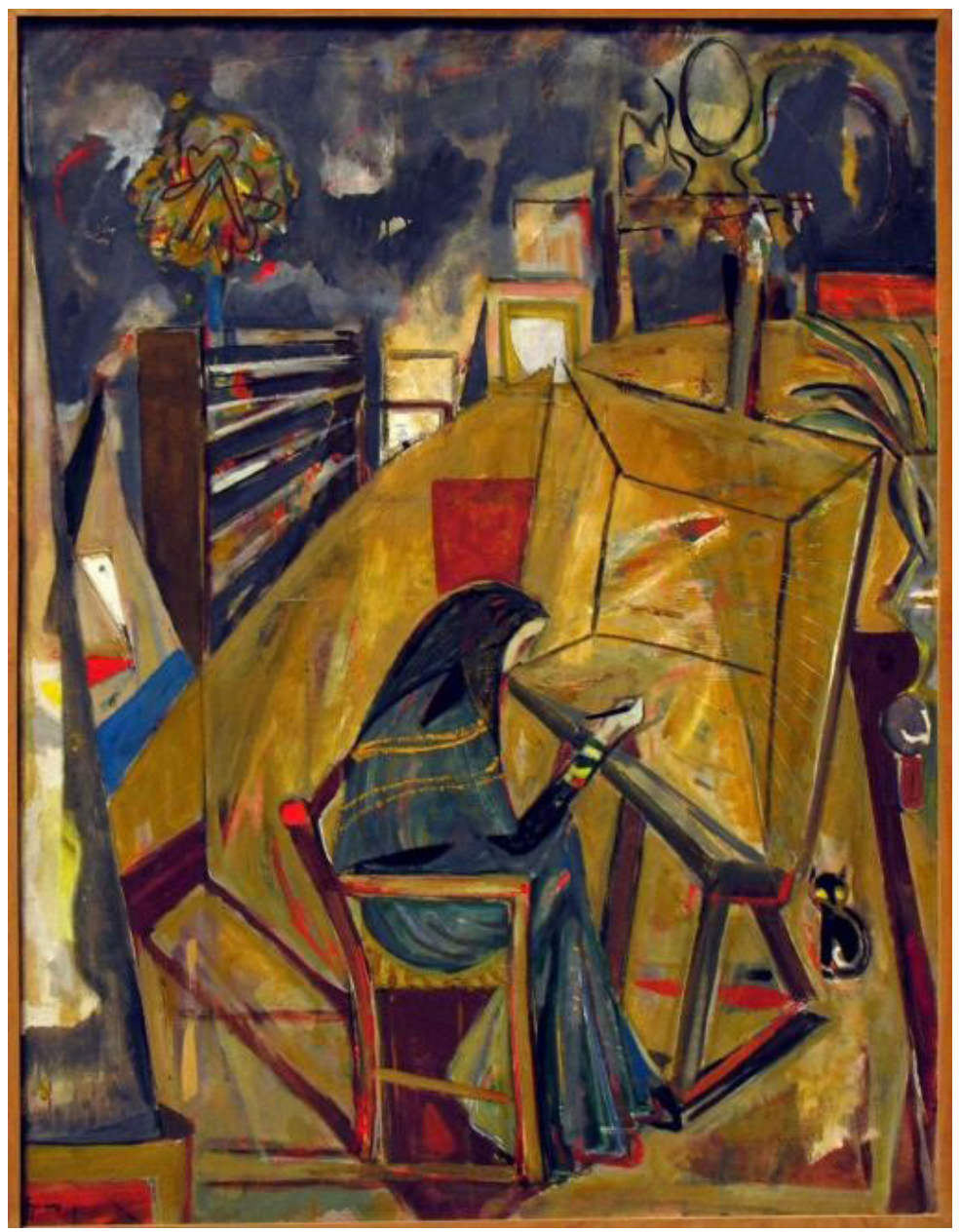

Árpad Szenes (1897-1985), Vieira da Silva no Atelier, 1946, óleo sobre tela $89,00 \mathrm{~cm}$ x 115,50 cm. Coleção Gilberto Chateaubriand - MAM/RJ.

Enciclopédia Itaú Cultural/São Paulo/Brasil. 
Indignada com os absurdos que moviam a humanidade atropelada pela ascensão de Hitler na Alemanha, Vieira não conseguiu processar o seu desenraizamento durante os sete anos de exílio que viveu no Brasil entre 1940 e 1947. O medo da guerra, a melancolia e a solidão vivenciadas no exílio, transformou-a em uma naúfraga engolida pelos redomoinhos de um mar revolto, conforme exposto no seu óleo sobre tela História trágico-marítima ou Naúfrago (1944). É como se Vieira estivesse revisitando seus espaços que, em um passado não tão distante, estavam flutuando em sua memória esgarçada pelo terror nazista e pelo medo da guerra. Assim, ao pintar A Floresta dos Errantes (La Forêt des Erreus), datada de 1941, Maria Helena insere-se em um túnel habitado por personagens cujas silhuetas nos remetem às figuras dos exilados. Sendo ela mesma uma apátrida a vagar pelo mundo, poderíamos, até mesmo, interpretar estas figuras como sendo dos judeus sem pátria dispersos pelas encruzilhadas da vida. Certamente, as razões que inspiraram Vieira da Silva a retratar florestas verde-amareladas não foram movidas pelas mesmas razões que motivaram o artista plástico e escultor polonês Frans Krajcberg (1921-2017) a apresentá-las como raízes contorcidas, queimadas pelo fogo.

A trama dos quadriláteros, círculos e triângulos empregada por Vieira da Silva remete aos seus dois mundos (exterior e interior) representados ora por florestas, bibliotecas e cidades destruídas onde vivem figuras encurraladas em um labirinto, ora em uma difícil partida de xadrez. Esta mesma temática inspirou sua tela Jogo de Xadres (1943) e também a novela Schachnovelle, do austríaco Stefan Zweig, escrita entre 1938 e 1941 e publicada em 1944, após o suicídio do autor em 22 de fevereiro de 1942. Assim como Maria Helena, Zweig explorou os traçados do xadrez para contextualizar o significado da vitória e da derrota na vida daqueles que temiam o nazismo.

Em suas correspondências com os amigos mais próximos - assim como na sua autobiografia e na novela Schachnovelle, por exemplo - Stefan Zweig mergulhou em seu mundo interior como uma forma de resistência, negando-se a comentar o tempo presente que, ao seu ver, é chocante. Vislumbra o seu passado como um edifício destroçado, derrubado no chão, em ruínas, conforme analisado por Mariana Xirico Holms. (Holms 2019: 84). Zweig tem plena consciência das "coisas vividas demais", referindo-se aquilo que não deveria nos tocar pessoalmente: "coisas que estavam invadindo a nossa vida e o equilíbrio interior, especialmente entre os judeus". Em uma de suas cartas ao amigo Felix Braun (1885-1973), escrita de Bath em 16 de outubro de 1939, confessou sentir-se como uma "anomalia vivente", um ser fora do lugar, ameaçado por um monstro:

"[...] nós somos anomalias viventes, que escrevem e pensam em uma outra língua que nos foi desautorizada, habitantes em um país e vinculados ao seu destino, ao qual não nos vinculamos completamente e em que somos meramente tolerados, judeus sem crença religiosa e sem desejo de ser judeu, pacifistas, que não deveriam se contradizer, quando se luta contra o monstro..." (Zweig 2005a: 263-264, apud Holms 2015: 45 ) 
Essas "anomalias viventes" podem ser (re)encontradas nas telas de Walter Levy (19051995), pintor de origem alemã radicado em São Paulo desde 1937. Considerado como o mestre do surrealismo no Brasil, Lewy criou personagens que percorrem paisagens lunares, muitas vezes iluminadas por grande sóis que se espalham como se fossem bolhas suspensas no ar. Estas figuras fantásticas são os seus eternos caminhantes, repletos de segredos, nem sempre tão estáticos.

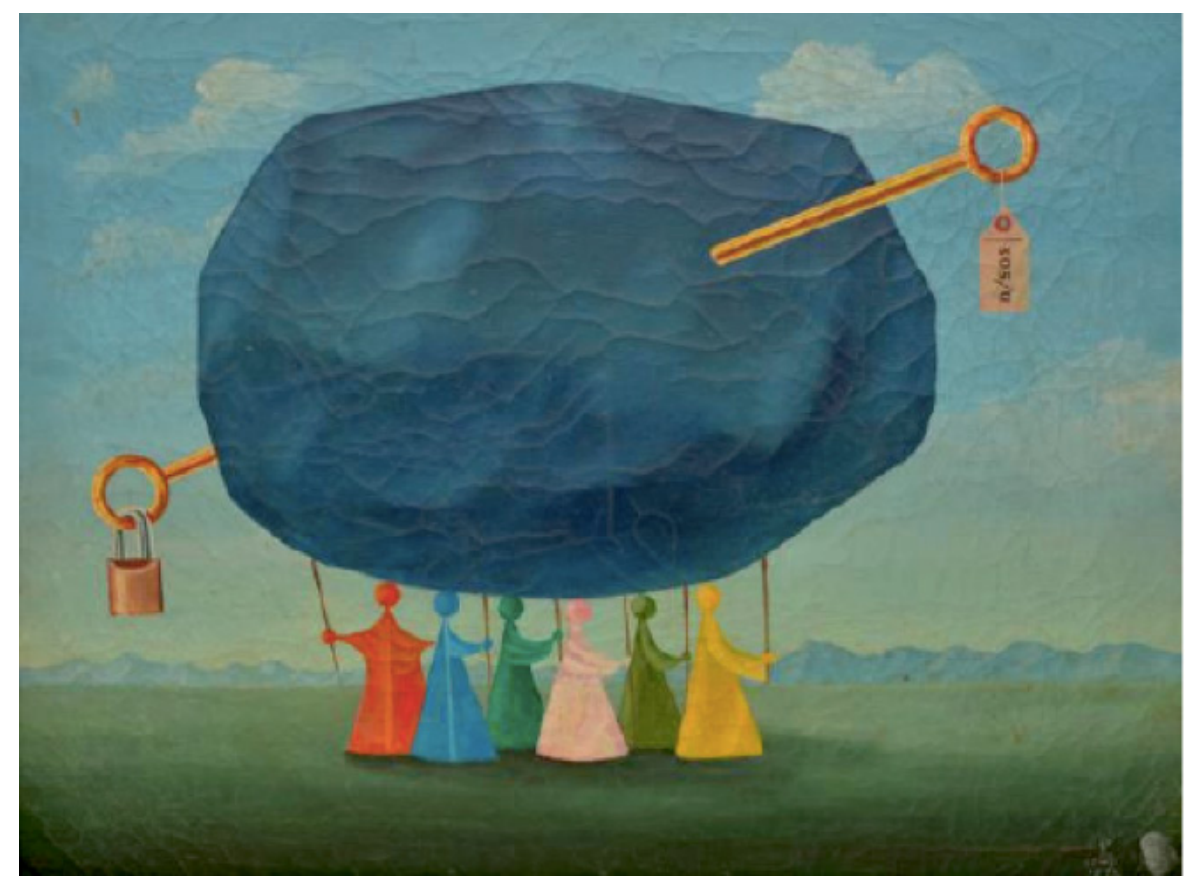

Walter Levy (1905-1995), sem título. São Paulo, 1992, óleo sobre tela, $64 \mathrm{~cm}$ x 83cm. Acervo Tucci/SP.

Assim como Walter Levy, Ulrich Becher anotou em seu Romanceiro Brasileiro seus estranhamentos diante das paisagens brasileiras ormanentadas com flores enormes que, no seu verdadeiro esplendor fantástico e maravilhoso, parecem ao europeu como "degeneradas, quase doentias", crescendo em um país enorme, onde "o galo canta antes de meia-noite." (Becher, 1979). Estas são, em sua essência, imagens e linguagens metafóricas que também podem ser reconstituídas através de algumas passagens do Diário Brasileiro, de Ernst Feder (1881-1964), exilado no Rio de Janeiro entre julho de 1941 a 1958:

É gloriosa a visão enquanto, na noite escura, o navio em sua majestosa calma adentra a gigantesca Bahia de Guanabara enquanto a iluminação aparentemente irreal de milhares e milhares de lâmpadas elétricas se desdobram à direita e à esquerda. É como se uma enorme cidade tivesse 
se preparado para nossa recepção e é inacreditável que noite após noite tenhamos um tal vislumbre enquanto toda a Europa está na escuridão. (Feder 1941)

Figuras "estranhas" povoam, na maioria das vezes, o imaginário e os cenários descritos pelos escritores e artistas refugiados no Brasil a partir de 1933. Cada qual expôs através dos seus filtros culturais e emocionais, os desconfortos diante do novo, nem sempre tão fáceis de serem digeridos. A maioria teve o seu olhar guiado por uma visão de mundo (Weltanschauung, na forma original em alemão) centrada em valores europeus, sendo a Europa o centro irradiador da civilização moderna. Neste caso, o eurocentrismo contribuiu para estigmatizar o Outro, incluíndo negros e os indígenas, descritos por sua vida miserável que fugia do padrão moderno ocidental. Movidos por essas imagens que faziam de si e do Outro, nem todos os refugiados conseguiram se desvencilhar dos preconceitos que interferiam na leitura da realidade brasileira. Através de uma passagem deixada em carta por Stefan Zweig ao seu amigo Felix Braun (1885-1973), temos a oportunidade de vislumbrar a construção da imagem de um Brasil "estranho", povoado por criados negros, onde tudo é muito "esplendidamente primitivo" onde o céu noturno é "simplesmente incrível".

Alugamos um pequeno bangalô, temos uma criada negra, tudo é esplendidamente primitivo, os burros carregados com bananas passam pelas nossas janelas; estamos rodeados por palmeiras e floresta virgem e o céu noturno estrelado é simplesmente incrível. O que nos falta são livros e amigos. (Carta de Stefan Zweig a Felix Braun, 21 de novembro de 1941).

Segundo Marlen Eckel, estudiosa dos exilados de língua alemã no Brasil, as expressões "pessimismo", "pessimista" ou "profundamente deprimido" se repetem nas anotações de Ernst Feder quando se refere ao estado d'alma do escritor Stefan Zweig. Tanto assim que, na manhã do dia 23 de fevereiro de 1942, Feder registrou em seu diário, "que o escritor poderia cometer suicídio", tal era o "ar de ausência" constatado em um encontro na noite anterior", retomando aqui estudos de Eckl. (Eckl 2012: 66)

Podemos afirmar que a força que move uma travessia forçada é a pulsão de vida que se destaca especialmente nas narrativas dos refugiados. Registros como estes de Zweig, Feder e Becher permitem a reflexão crítica sobre a subtração de direitos, perseguições em razão de raça ou religião, desterritorialização, violência, trauma, sensibilidade, integração cultural e social no país de destino. Portanto, devemos estar atentos à produção de sentidos que dependerá do trabalho de interpretação e da sensibilidade de cada observador/leitor para identificar as marcas de dor, sofrimento e/ou de felicidade. Assim conseguiremos perceber como eles/ elas, refugiados(as), construíram versões sobre si como sujeito em constante mutação, cujas narrativas podem nos ajudar a repensar as suas relações com o "velho"e o "novo" mundo, assumindo novos papéis e posturas criativas, dando novos sentidos às suas vidas.

O desafio está em identificar nestes múltiplos mundos os vestígios da violência totalitária, assim como as marcas da liberdade de "ser" e "estar-no-mundo", e ao mesmo tempo, perce- 
ber como estes atores retrataram o mundo que viram, proposta que nos remete às obras Brasil, País do Futuro ( 1941), e 0 mundo que eu vi (1942), de Stefan Zweig:

Às vezes quando, curioso, andava pelas favelas, esses pitorescos casebres dos negros que ficam nas encostas dos morros no meio da cidade como gaiolas de pássaros, tive a consciência pesada e um mau pressentimento. Pois afinal eu fora lá por curiosidade para ver o degrau mais primitivo da vida e observar nos barracos de barro e de bambu, indefesos contra todo olhar, as pessoas em sua condição mais primitiva e, com isso, indevidamente espiar para dentro de suas casas e sua vida particular. (Zweig 2005: 274)

Movidos pelos seus estranhamentos, os refugiados do nazifascismo não ficaram alheios aos rituais afro-brasileiros que, de alguma forma, os colocavam diante de situações inéditas de sons e transe. O samba, o carnaval e a macumba foram, para muitos, uma forma de adentrar ao mundo simbólico do sujeito "em transe" e de conhecer de perto os espaços afro-brasileiros onde o corpo ocupa um lugar privilegiado. A impressão que temos - observando as suas representações ou analisando suas narrativas - é de que eles foram envolvidos por um grande redomoinho urbano que colocou em xeque seus conceitos de primitivo e primitivismo.

Tanto as pintoras Lisbeth (Lise) Forell e Vieira da Silva (1946), como o escritor austríaco Ulrich Becher, transformaram estas temáticas em manifestos contra o nacional-socialismo, o antissemitismo e a pobreza vivenciada pelo povo brasileiro. Lise Forell (1924- 201?), de origem tcheca, desembarcou no Rio de Janeiro em setembro de 1941 fugindo das perseguições nazistas. Uma das suas primeiras obras apresentadas no Brasil - O Judeu Errante, exposto no XLIX Salão Nacional de Belas Artes em 1943 - motivou o crítico de arte Pietro Maria Bardi a defini-la como um "documento notável marcado pela patética força de sentimento por sublinhar o evento mais degradante da humanidade do século XX". Felizmente, Lise Forell entregou-se de corpo e alma aos ritmos e às cores deste país tropical:

O sombrio e o pânico que sopravam na outra costa do Atlântico se desfizeram ao encontro das batucadas, da intensa impressão da favela, dos desprendimento com que a gente desenvolve sua vida alegre. Lise pintou com verve o Brasil, alcançando as cores dos diapasões mais brilhantes, construindo e imaginando suas cenas com o instinto que Gauguin chamava "Naiveté", que não deve ser confundido com o trabalho cada vez mais numeroso dos primitivos". (Bardi 1943 apud Leite 2014)

Ulrich Becher, por sua vez, transferiu para as suas peças de teatro Samba (1951) e Makumba (1958), sua postura de constestação ao regime nazista, rancores guardados desde 1932 quando teve a sua coleção de contos Männer machen Fehler (Homens cometem erros) queimados pelos nacional-socialistas. Tornou-se assim, segundo Marlen Eckl, "o mais jovem dos autores proscritos e proibidos do Terceiro Reich, em 1933" (Eckl 2011: 132). Em sua peça Samba, apresentada em 1951 no Theater in der Josephstadt, o escritor público vienense valeu-se das suas 
memórias do carnaval carioca e de figuras reais da sua convivência com o grupo de refugiados liderados por Görgen, para lançar suas críticas ao nacional-socialismo e ao governo de Getúlio Vargas (1937-1945). Desta forma, ele retratou a sociedade brasileira e a fascinação dos exilados europeus pelo samba e pelo carnaval. Maiores detalhes sobre estes escritos podem ser lidos no artigo de Marlen Eckl, "O exílio no Brasil ou 'A Europa no meio do mato: desencontros entre Stefan Zweig e Ulrich Becker”. (Eckl 2011: 127-148).

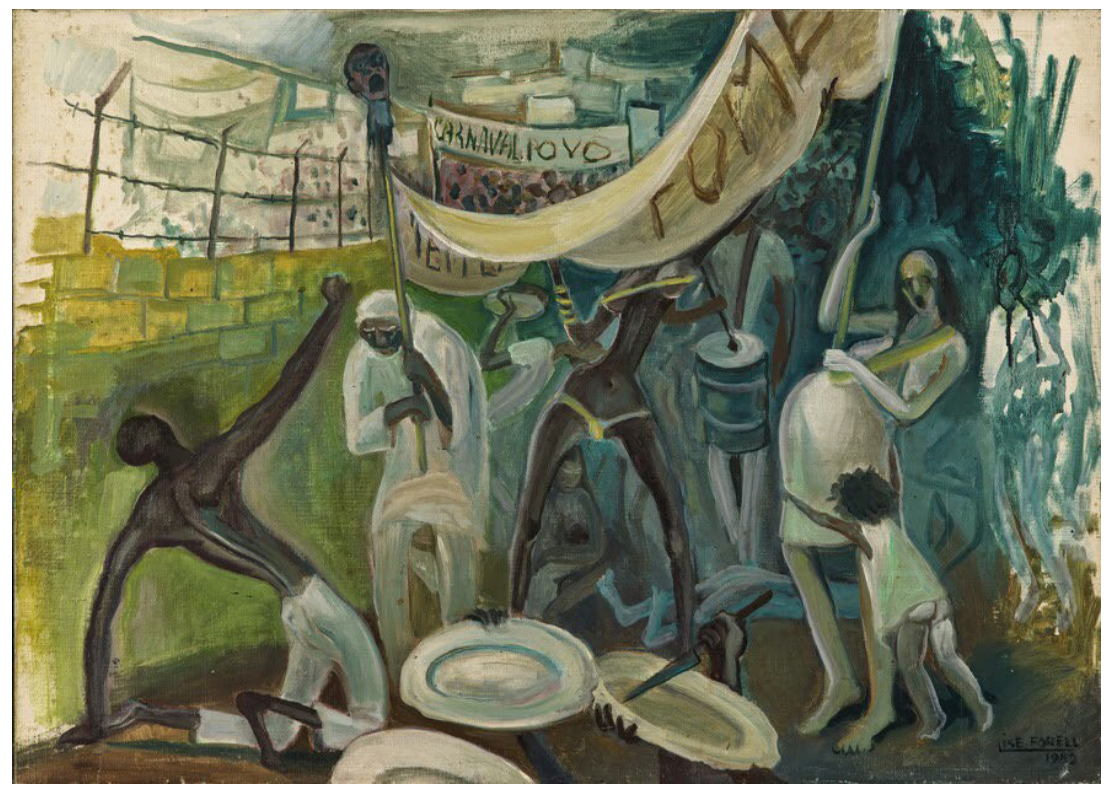

Lise Forell. Carnaval da fome. São Paulo, 1983.

Reprodução impressa, cortesia da artista.

Acervo Tucci/SP

\section{Considerações finais}

Os exemplos aqui citados explicitam o significado de tornar-se apátrida em tempos sombrios por implicar na mutação da alma ou seja, num rito de passagem que envolve a transformação do sujeito em um ser vitorioso por recuperar o direito de viver: viver com dignidade, como um cidadão com nome e sobrenome. O processo de reconquista dos direitos de cidadania exigiu de todos os refugiados do nazifascismo um árduo processo de reconstrução de identidade. No entanto, nem todos conseguiram superar seus traumas e ultrapassar as barreiras impostas pelo terror nazista, ainda que vivessem escondidos em lugares imaginários.

Através das narrativas e das representações produzidas pelos artistas e intelectuais conseguiremos verificar como eles lidaram com as mutações de um mundo em crise e a fragilidade 
do ser humano. Cada qual, à sua maneira, procurou submergir aos seus naufrágios, ainda que simbólicos, valendo-se da arte e da escrita para expor suas ansiedades e traumas. A abstração - a exemplo das obras de Vieira da Silva - extrapolou o exercício da forma pela forma ao expor as condições de alienação e depressão do artista/refugiado, da mesma forma que alguns espaços nos colocam no lugar do espectador forçando-nos a projetar significados. Retomo aqui a proposta de Roger Chartier de que, através das práticas discursivas, poderemos identificar as formas que eles escolheram para "reordenar o mundo" após o caos, suas noções de distâncias e suas formas diferenciadas de interpretação das novas realidades.

\section{NOTAS}

* Maria Luiza Tucci Carneiro é Historiadora e Professora Senior do Departamento de História da FFLCH-Universidade de São Paulo. Atualmente coordena o Laboratório de Estudos sobre Etnidade, Racismo e Discriminação -LEER/USP), junto ao qual desenvolve o projeto Travessias - Enciclopedia de Artes. Literatura. Ciências: o legado dos refugiados do nazifascismo. Brasil, 19332023. Autora de: Impressos Subversivos: Arte, Cultura e Política. Brasil, 1924-1964 (Intermeios, 2020); Dez Mitos sobre os Judeus, 2ed. (Ateliê Editorial, 2020); Cidadão do Mundo: O Brasil diante do Holocausto e dos refugiados do nazifascismo (Perspectiva, 2010), dentre outros.

${ }^{1}$ Comunicação apresentada por Maria Luiza Tucci Carneiro na Jornada de Estudos "Sous des cieux étrange(r)s/ Sob céus estranhos: Mémoires de la Seconde Guerre Mondiale/Memórias da Segunda Guerra Mundial: exílio e devir em Portugal e Brasil", organizada por Karina Marques. Université de Poitiers, França, 26 nov. 2020. 


\section{Bibliografia}

Becher, Ulrich (1962), Brasilianischer Romanzero. Hamburgo, Rowohlt.

Bohunovsky, Ruth (2008), "O Brasil de Ulrich Becher no Romanceiro Brasileiro: a harmonia em questão", in Pandemonium Germanicum, 12, 2008, 80-99. Disponível em: https:// www.researchgate.net/publication/304212854_O_Brasil_de_Ulrich_Becher_no_ Romanceiro_Brasileiro_a_harmonia_em_questao/link/577d5efco8aeaee3b27e3b2c/ download. Acesso em: 14 set. 2021.

Carneiro, Maria Luiza Tucci (2010), Cidadão do Mundo: o Brasil diante do Holocasuto e dos judeus refugiados do nazifascismo, 1933-1948. São Paulo: Perspectiva (Lit Verlag, 2014; L'Harmattan, 2016).

-- (2021), Dez Mitos sobre os Judeus, 3ed. Coimbra: Imprensa da Universidade de Coimbra; Ateliê Editorial.

- - (1996), Brasil, Um Refúgio nos Trópicos (Brasilien, Fluchtpunkt in den Tropen), edição bilingue. Tradução: Dieter Strauss e Angel Bojadsen. São Paulo: Estacão Liberdade; Instituto Goethe de São Paulo, 1996.

Eckel, Marlen, "A flor do exílio" - A amizade de Stefan Zweig e Ernst Feder vista a partir do Diário Brasileiro de Feder", in WebMosaica, Revista do Instituto Cultural Judaico Marc Chagall v. 4, n.2 (jul-dez) 2012.

-- (2011), "O exílio no Brasil ou 'A Europa no meio do mato: desencontros entre Stefan Zweig e Ulrich Becker'", in Revista IEB, n.53, mar/set, pp. 127-148.

Feder, Ernst (1948), Diário Brasleiro (Brasilianisches Tagebücher), v. 15 (1941-1943); v. 16 (19441945); v. 17 (1946-1947); v. 18 (1948). Ernst Feder Collection, AR 7040. Leo Baeck Institute. New York, EUA.

Flusser, Vilém (2007), Bodenlos, uma autobiografía filosófica. São Paulo: Anna Blume.

Hobsbawm, Eric (1995), A Era dos Extremos: o breve século XX. Traduzido por Marcos Santarrita. São Paulo: Companhia das Letras.

Holms, Mariana Chirico Machado (2019), "Um palestrante narrando slides": o sujeito autobiográfico esquivo em Die Welt von Gestern, de Stefam Zweig. Dissertação apresentada à area de Língua e Literatura Alemã da FFLCH-Universidade de São Paulo, 2019. Disponível em: https://www.teses.usp.br/teses/disponiveis/8/8144/tde-12122019161707/publico/2019_MarianaChiricoMachadoHolms_VCorr.pdf. Acesso em: 17 set. 2021.

Jiubilut, Liliana Lyra (2007), O Direito Internacional dos Refugiados: e sua aplicacão no ordenamento jurídico brasileiro. São Paulo: Método.

- - et allii (2018), Migrantes Forçados: conceitos e contextos. Boa Vista: EDUFRR.

Kestler, Izabela Maria Furtado (2003), Exílio e Literatura: escritores de fala alemã durante a época do nazismo, 1a ed., Tradução de Karola Zimber. São Paulo: Edusp.

Lasch, Christopher (1986), O Mínimo Eu: sobrevivência psíquica em tempos difíceis. Traducão: José Roberto Martins Filho. São Paulo; Brasiliense.

LEITE, Mazé (2014), "Lise Forell: uma vida para a arte", in Arte \& Ofício. Disponiível em: 
https://artemazeh.blogspot.com/2014/09/lise-forell-uma-vida-para-arte.html. Acesso em: 17 set. 2021.

Marques, Karina (Org.) (2018), Ilse Losa: estreitando laços. Correspondência com os pares Lusófonos (1948-1999). Porto, Edições Afrontamento.

Moreira, Julia Bertino/ Sala, José Blanes (2018), "Migracões Forçadas: categorização em torno do sujeto migrantes", in Jubilut, Liliana Lyra et allii. Migrantes Forçad@s: conceitose contextos. Boa Vista, EDUFRR: 15-42.

Silva, Maria Helena Vieira da (1986), "Vivíamos assim como uma borboleta", in Morais, Frederico. Tempos de Guerra: Hotel Internacional/Pensão Mauá. Rio de Janeiro: Galeria de Arte Banerj, n.p. (Ciclo de Exposições sobre Arte no Rio de Janeiro, 6).

Rosenthal, Gisela (1998), Vieira da Silva 1980-1992. À Procura do Espaço Desconhecido. Lisboa, Colônia, Taschen.

Zweig, Stefan (1942), O Mundo que eu ví. Minhas Memórias. Tradução de Odilon Gallotti. Rio de Janeiro, Editora Guanabara.

- (1941), Brasil, País do Futuro. Trad. Odilon Galotti. Rio de Janeiro, Guanabara. 